\title{
糖尿病患者における抗菌骩の口腔組織内濃度移行性
}

\author{
三宮慶邦・深田健治・星 佳 芳 \\ 山崎 卓・酒向 誠・丸岡靖史 \\ 扇内秀樹
}

\section{Penetration of antibiotics into oral tissue in diabetic patients}

\author{
Yoshikuni SanGU $\cdot$ Kenji FuKada $\cdot$ Keika Hoshi \\ Takashi YAMAZAKI $\cdot$ Makoto SAKO $\cdot$ Yasubumi MarUOKA \\ Hideki OGIUCHI
}

\begin{abstract}
In diabetic patients, the microcirculation is impaired in oral mucosal capillaries as well as in the retina. Consequently, the concentration of drug transferred to the oral mucosa is expected to be lower than in healthy persons. Therefore, we orally administered an antimicrobial drug before oral surgery and evaluated its transfer to oral tissue. The study group comprised 30 diabetic patients who visited our department and underwent tooth extraction. Differences between the diabetic patients and a control group were statistically analyzed. Before tooth extraction, an antimicrobial drug was orally administered. Immediately after operation, we obtained samples of peripheral blood, blood retained in the extraction cavity, and gingival tissue of the surrounding area. The concentrations of antimicrobial drug in the serum and gingiva were determined by bioassay. There was no significant difference between the diabetic patients and the control group. Therefore, more detailed studies of additional patients are necessary. Our results suggest that an increase in the dose of antimicrobial drugs is not necessary in patients with relatively well controlled diabetic mellitus.
\end{abstract}

Key words: diabetes mellitus (糖尿病), microangiopathy（細小血管症）, antimicrobial drug (抗菌哓), oral mucosa（口腔粘膜）

\section{緒言}

糖尿病患者の易感染性や歯周症の増悪については周知の 事実であり, 通常口腔外科領域の臨床において, 糖尿病患 者の抜歯などの口腔観血的処置時に抗菌剤の投与は確実に 行われるべきである. 糖尿病性細小血管症は, 口腔粘膜毛 細血管においても特徴的に発現するとされており 1,2$)$, 糖 尿病患者では, 網膜と同様に口腔粘膜毛細血管においても, 微小循環障害が発生しているものと考えられ, 口腔粘膜へ の抗菌剤移行濃度も健康人に比し劣ることが予測される。 そこで今回, 抗菌剤を術前に経口投与し, 口腔組織への移 行濃度について検討を行った。

東京女子医科大学医学部歯科口腔外科学教室

(主任 : 扇内秀樹教授)

Department of Oral and Maxillofacial Surgery, School of Medicine, Tokyo Women's Medical University (Chief: Prof. Hideki Ogiuchi)

受付日 : 平成11年 5 月 20 日

\section{対 象 症 例}

1996年10月から1998年 1 月までの 1 年 3 か月間に東京女 子医科大学歯科口腔外科を受診し, 抜歯を行った糖尿病患 者で, 15歳から81歳までの, 男性18例, 女性12例の計30例で ある.また全身疾患を有さない 21 歳から 65 歳までの健康人 23例を対照群とし, unpaired t testによる 2 群間の抗菌剂 濃度の有意差検定を行った. なお本研究の内容については 被験者に対し十分な説明を行い，了承を得た.

糖尿病患者の背景としては, 罹患年数は 2 年から 30 年で 平均 12.47 年, $\mathrm{HbA} 1 \mathrm{c}$ は $5.5 \%$ ～ $12.5 \%$ で，うち 2 例が $10 \%$ 台を超えていたが䍜患年数は 2 年と 8 年であった. 平均で は7.6\%と比較的良好にコントロールされていた（表 1 ).

\section{方法}

抜歯前に経口で抗菌剂を投与し, 抜歯直後の末梢血, 抜 歯窩貯留血液と歯肉を採取し, 血清中および歯肉中の抗菌 剤濃度を bioassay 法で測定した。この方法の詳細は下記 
のとおりである。

(1) 拔歯約 1 時間前に lomefloxacin hydrochloride （200mg）を経口投与させる.

(2) 術前の血糖値を手指または耳梁より採取した血液 で簡易血糖測定器（ADVANTAGE）(ロッシュ,アメリ カ）を用いて測定する.

( 3 ） 2 \%歯科用キシロカインで局所浸潤麻酔後抜歯を 行う。

（4）抜歯窩に貯留した血液中に $6 \mathrm{~mm}$ thick paper disk を浸し吸収させただちに凍結保存する。

(5) 同時に周囲歯肉を約 $1 \mathrm{~g}$ 採取し, 測定時まで凍結保 存する.

（6）術直後に正中皮静脈より採血し，ただちに遠心分 離後その血清を凍結保存する。

抗菌剤の移行濃度の測定は, 検定菌に E. coli 7437, 検定 培地に Trypto-Soy Agar（栄研，東京）を用いて, 血清試 料については正常血清で調製した標準血液（2.0 0.06 $\mu \mathrm{g}$ $/ \mathrm{ml})$ を用い, 歯肉組織は組織 $1 \mathrm{~g} に 2 \mathrm{ml}$ のリン酸緩衝液 (pH 7 ) を加えホモジナイズし，その上清についてリン酸

\section{表 1 患者背景}

\begin{tabular}{|c|c|c|c|}
\hline 罹病期間 & 2 ～30年 & 平 均 & $12.47 \pm 8.66$ 年 \\
\hline $\mathrm{HbA} 1 \mathrm{c}$ & $5.5 \sim 12.5 \%$ & 均 & $7.61 \pm 1.65 \%$ \\
\hline
\end{tabular}

\begin{tabular}{ccc}
\hline 罹病期間 & $\mathrm{HbA} 1 \mathrm{c}$ & $\mathrm{HbA} 1 \mathrm{c}$ の平均 \\
\hline $2 \sim 5$ 年 & $5.5 \sim 12.5 \%$ & $6.30 \%$ \\
〜 10 年 & $7.1 \sim 11.5 \%$ & $8.80 \%$ \\
10 年以上 & $5.8 \sim 7.9 \%$ & $7.60 \%$ \\
\hline
\end{tabular}

緩衝液 $(\mathrm{pH} 7)$ 中に調製された標準血液（2.0〜0.06 $\mu \mathrm{g} /$ $\mathrm{ml}$ ）を用いて帯培養法3，4）（Band-culture method）で測 定し, 抜歯創試料については正常血液中に調製した標準血 液 $(20 \sim 0.32 \mu \mathrm{g} / \mathrm{ml})$ を用いてペーパーディスク法で測 定した.

\section{結果}

糖尿病患者の術前血糖值は $107 \sim 290 \mu \mathrm{g} / \mathrm{dl}$, 術直後の 血糖值は164 291 $\mu \mathrm{g} / \mathrm{dl}$ であった. 麻醉, 抜歯という刺激 による血糖值の上昇はあまり認められなかった．全例60～ 80分後に検体を採取できた。 その結果血清中濃度は糖尿病 患者では平均值 $1.129 \pm 0.635 \mu \mathrm{g} / \mathrm{ml}$, 対照群では平均值 $1.53 \pm 0.882 \mu \mathrm{g} / \mathrm{ml}$ であった (図 1 , 表 2 ). 歯肉中濃度で は, 糖尿病群が平均值 $1.324 \pm 1.037 \mu \mathrm{g} / \mathrm{g}$, 対照群が平均 値 $0.924 \pm 0.513 \mu \mathrm{g} / \mathrm{g}$ であった(図 2 , 表 2 ). それぞれの 対血清比は糖尿病群で 1.173 , 対照群が0.604であった. 抜 歯窩貯留血液の血清中濃度では糖尿病群が平均值 $1.255 \pm$ $0.738 \mu \mathrm{g} / \mathrm{ml}$, 対照群が平均值 $0.920 \pm 0.615 \mu \mathrm{g} / \mathrm{ml}$ で あった (図 3 , 表 2 ). 対血清比は糖尿病群で 1.112 , 健康人 が0.601という結果であった.これらのいずれにおいても糖 尿病群と対照群の間には有意差は認められなかった。

\section{考察}

糖尿病患者は種々の合併症を引き起こすが，その発症， 進展を助長する因子も多彩であり，特に細小血管症に及ほ す発症・進展因子もさまざまである. 高血糖が細小血管症 を引き起こす機序は解明されていないが, 蛋白質のグリ ケーション 5), ポリオール活性六進 ${ }^{6)}$, フリーラジカルの 産生立進, プロテインキナーゼ C の活性異常 7), あるいは

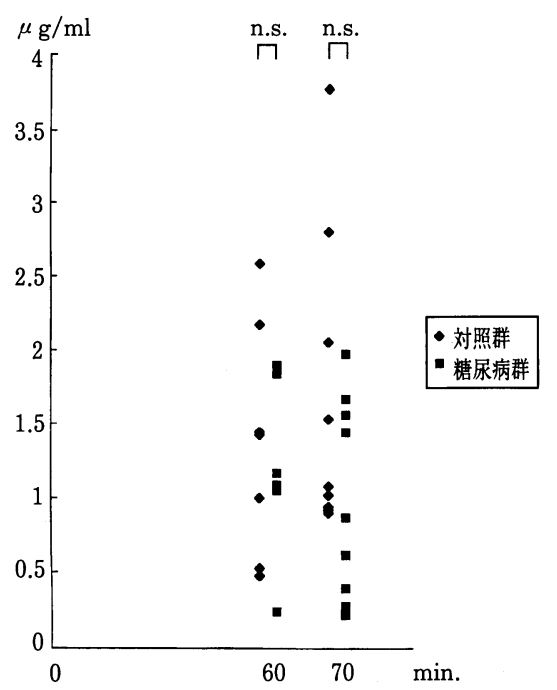

図 1 lomefloxacin 血清中濃度

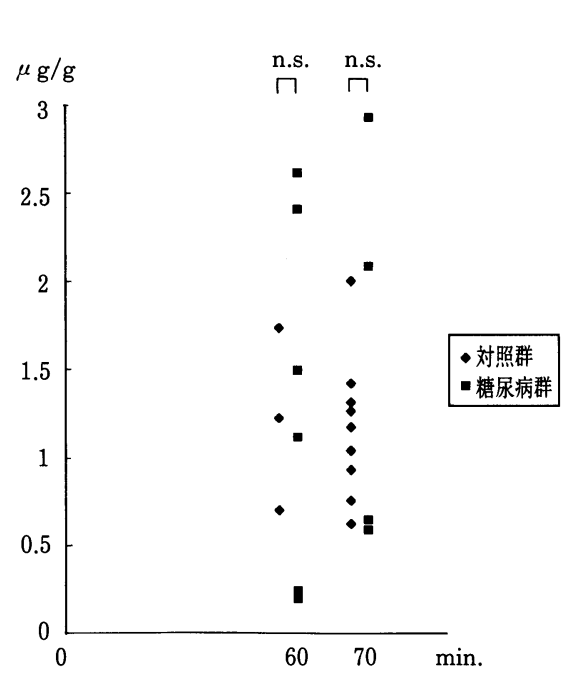

図2 lomefloxacin 歯肉中濃度

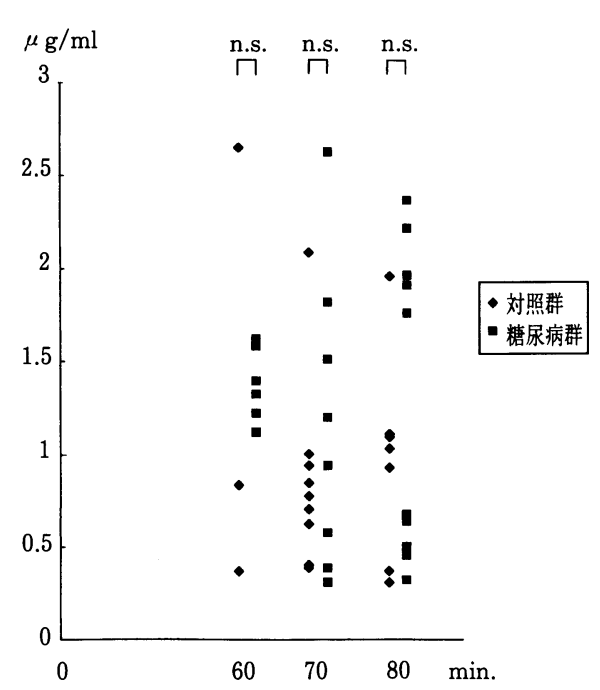

図 3 lomefloxacin 抜歯窩内血清中濃度 
表 2 lomefloxacinの移行濃度

\begin{tabular}{|c|c|c|c|c|c|c|}
\hline & 血 & 清 & 歯 & 肉 & 抜歯窩 & （血 清） \\
\hline & 対照群 (17例) & 糖尿病群（16例） & 対照群 (17例) & 糖尿病群（11例） & 対照群 (23例) & 糖尿病群 (30例) \\
\hline 平均 值 & $1.53 \pm 0.882 \mu \mathrm{g} / \mathrm{ml}$ & $1.129 \pm 0.635 \mu \mathrm{g} / \mathrm{ml}$ & $0.924 \pm 0.513 \mu \mathrm{g} / \mathrm{g}$ & $1.324 \pm 1.037 \mu \mathrm{g} / \mathrm{g}$ & $0.92 \pm 0.615 \mu \mathrm{g} / \mathrm{ml}$ & $1.255 \pm 0.738 \mu \mathrm{g} / \mathrm{ml}$ \\
\hline 最小值 & $0.47 \mu \mathrm{g} / \mathrm{ml}$ & $0.22 \mu \mathrm{g} / \mathrm{ml}$ & $0.13 \mu \mathrm{g} / \mathrm{g}$ & $0.2 \mu \mathrm{g} / \mathrm{g}$ & $0.24 \mu \mathrm{g} / \mathrm{ml}$ & $0.3 \mu \mathrm{g} / \mathrm{ml}$ \\
\hline 最 大 值 & $3.76 \mu \mathrm{g} / \mathrm{ml}$ & $1.97 \mu \mathrm{g} / \mathrm{ml}$ & $2.0 \mu \mathrm{g} / \mathrm{g}$ & $2.93 \mu \mathrm{g} / \mathrm{g}$ & $2.65 \mu \mathrm{g} / \mathrm{ml}$ & $2.62 \mu \mathrm{g} / \mathrm{ml}$ \\
\hline 対血清比 & & & 0.604 & 1.173 & 0.601 & 1.112 \\
\hline
\end{tabular}

血液凝固・レオロジーの異常などが主要な危険因子とされ ている ${ }^{8)}$. また糖尿病䍜病期間と細小血管症の発生・進展 への危険性を経年的に観察すると, その発症が増加し, こ とにコントロール不良の状態が長期間持続すると, 特有の 細小血管症の発症が明らかにされている. 反対に, diabetes control and complication trial (DCCT, 1993) という大 規模疫学調査では, 血糖を厳格にコントロールすることに より細小血管障害を予防することが実証されている ${ }^{9)}$.さ らに糖尿病患者の易感染性の原因は単一因子によるもので はなく，多くの因子が関与していると考えられるが，中で も末梢組織の微小循環不全が生ずると, 感染病巣への白血 球の動員や特異抗体の到達を妨げ, 組織酸素分圧を低下さ せ, 細菌の発育に適した状態を作り出し, 抗生物質の移行 を低下させるなど細菌の発生を促すと同時に難治性とな $る^{10,11)}$.

最近の薬剤は比較的高濃度, かつその持続時間も長く口 腔外科領域に広く応用されている. 現在まで種々の抗菌剂 の口腔組織移行濃度について検討がなされているが, 糖尿 病患者を対象とした歯肉への移行濃度の検討は行われてお らず,また著者らは口腔内歯肉にもこの微小循環障害が起 きていることを予測し, 抗菌剂移行濃度の測定を手段とし て検討を行った。しかしながら今回の調査では，他の経口 用抗菌薬と同様に個体差が大きかったこと, 特に抜歯を行 う部位に程度の異なる炎症状態が存在していることや, 対 象とした糖尿病患者が比較的良好にコントロールされてい る症例が多かったことで, 健康人との有意差は見い出せな かった。したがって今後は, 症例数を増やしさらに詳細な 検討が必要であると考えられる。なお今回の結果より，比 較的良好にコントロールされている糖尿病患者に対し，適 応量以上の抗菌剤の増量は必要がないと考える.

\section{結語}

糖尿病患者と健康人に対し経口抗菌剤を投与し，抜歯直 後の口腔組織濃度を測定した結果, 両者に有意差は認めら れなかった。
本論文の要旨は第43回日本口腔外科学会総会 (1998年10月 松本市) で発表した。

\section{文献}

1）片桐重雄 : 口腔粘膜における糖尿病性細小血管症一 微小循環と赤血球形能について一. 歯科学報 89: 1127-1141 1989.

2) Montironi, R., Sisti, S., et al.: Clinical significance of the histomorphometric evaluation of diabetic microangiopathy in the oral mucosa. Pathol Res Pract 185: 781-785 1989.

3）大久保滉，岡本緩子 : 体液組織液中の抗生物質濃度 の生物学的微量測定一とくに帯培養法 Bandculture method について一. 日本臨床 31: 441-447 1973.

4）木村靖雄, 土肥正善, 他 : 抗生剂の微量定量一帯培 養法の応用. Chemotherapy 25: 449-450 1977.

5）谷口直之：グリケーション反応. Diabetes Frontier 4: 398-402 1993.

6）堀田 饒, 坂本信夫 : 糖尿病性細小血管症と aldose reductase 阻害剂. 小坂樹徳, 赤沼安夫編 : 糖尿病 学1990. 第 1版, 診断と治療社, 東京, 1990, 387-417 頁.

7) King, G.L., Shiba, T., et al.: Cell culture model for the study of vascular complications of diabetes. Ruderman, N., Williamson, J., et al. eds.: Hyperglycemia, Diabetes, and Vascular Disease. Oxford University Press, 1992, p162177.

8）岩本安彦 : 糖尿病の代謝異常. 堀 貞夫編著 : 糖尿 病眼科学一日一課. 第 1 版, メディカル葵出版, 東 京, 1996, 3-5頁.

9) The DCCT Research Group: The effect of intensive treatment of diabetes on the development and progression of long-term complications in IDDM. N Engl J Med 329: 977-326 1993.

10）大島康男, 磯貝 庄: 糖尿病と感染症. 池田義雄 編 : 新糖尿病合併症治療のチェックポイント. 第 1 版, 日本メディカルセンター, 東京, 1986, 242-252 頁.

11）古家大祐：感染症と糖尿病合併症。繁田幸男，古川 隆一編 : 糖尿病と合併症. 第 1 版, 医歯薬出版, 東 京, 1995, 223-228頁. 